\title{
ALENCAR E A FORMAÇÃO DO PENSAMENTO CRÍTICO SOBRE O PORTUGUÊS DO BRASIL
}

Marli Quadros Leite*

RESUMO: Neste artigo, nosso objetivo é o de estudar, no quadro da historiografia linguística, a metalinguagem de J osé de Alencar, produzida entre 1865 e 1870 . O texto mostra que, embora o discurso de Alencar constitua o discurso fundador da crítica à variedade brasileira do português, seu pensamento linguístico era confuso e seu objetivo, mais que lutar pela autonomia e independência da "língua brasileira", em face da variedade europeia, era o de justificar e defender sua própria linguagem literária.

Palavras-chave: Português do B rasil; historiografia linguística; variedade linguística; metalinguagem.

\section{PRIMEIRAS CONSIDERAÇõeS}

O estudo do pensamento crítico sobre o português do $B$ rasil $(\mathrm{PB})$ permite ao leitor conhecer não somente os principais temas que ensejam a discussão sobre características linguísticas, propriamente ditas, citadas nos textos, como também dados sociais e científicos a respeito dos quais se assentam os comentários. Os autores, bem ou mal, referem-se à literatura filosófica, sociológica e linguística em voga em cada época, para argumentar em favor das teses que, a cada mo-

(FFLCH - USP) 
mento, defendem. Por isso, por meio desses ensaios metalinguísticos é possível perceber que teorias e filosofias vigoram em cada época. Especificamente, porém, nosso objetivo será o de investigar a metalinguagem e, subsidiariamente, comentar essas ideias e sua influência no campo dos estudos linguísticos, quando relevantes à compreensão da posição assumida pelo autor.

A produção metalinguística sobre o PB é extensa e importante ao conhecimento histórico por que passou a língua no B rasil. A leitura dos mais importantes textos de interpretação, produzidos sobre a variedade brasileira do português, levou-nos à conclusão de que ela pode ser divida em dois grandes blocos: o primeiro estende-se de 1825-26, com a publicação do texto do Visconde de Pedra B ranca até metade do século XX, depois da Semana de Arte Moderna; o segundo inicia-se com a publicação do livro Introdução à língua portuguesa noB rasil, de S erafim da Silva Neto, em 1950, e, pode-se dizer, continua até hoje porque suas ideias ainda são debatidas.

A produção desse pensamento crítico configurou três estágios distintos de interpretação sobre o português do B rasil: a. levantamento de diferenças (léxicas) entre o PB e o português europeu (PE); b. constituição da ideologia nacionalista sobre a língua; c. levantamento de características - léxicas e gramaticais - sobre o PB; d. constituição da metalinguagem científica sobre o PB. Neste artigo, voltaremos nossa atenção sobre o estágio $\mathrm{b}$, analisando o pensamento crítico de J osé de Alencar sobre a língua portuguesa praticada no B rasil

Privilegiamos examinar a metalinguagem de J osé de Alencar, dentre outras, pela importância histórica que ela adquiriu, já que a literatura que praticava simultaneamente à produção metalinguística, ou o inverso, representa o "discurso fundador" da literatura brasileira. Nossa tese aqui, contudo, é a de que o discurso metalinguístico do autor não defende com propriedade o discurso literário que produziu, 
porque se fez na base da defesa de usos próprios $^{1}$ e de comentários teóricos nem sempre corretos ou claros. Além disso, a tese do nacionalismo, de que a língua é a nacionalidade do povo, foi profícua até começos do século XX. O nacionalismo alencariano era alicerçado na proclamação da liberdade linguística brasileira em face das normas quinhentistas portuguesas que, então, eram praticadas na língua escrita no Brasil.

\section{José De Alenc Car}

O papel de J osé de Alencar no cenário da literatura brasileira é indiscutível. Pode-se não gostar de sua produção, reputá-la irregular e inconsistente, mas não se pode negar a ele o mérito de ter introduzido o discurso brasileiro na literatura. E m que consiste esse discurso? Consiste, realmente, da utilização de um repertório léxico e gramatical brasileiro? Responder a essas indagações não é fácil, porque, no imaginário brasileiro, Alencar é o "introdutor da língua brasileira" na literatura. Mas vamos nos lançar aqui à tarefa de negar parcialmente essa afirmação, usando para isso a metalinguagem do próprio Alencar. Mas se ele não empregou em sua literatura a língua do povo, a língua da rua, aquela realmente usada pelo brasileiro na prática linguística diária, e nem empregou a língua portuguesa calcada nos moldes do classicismo português, que era, até então, o modelo dos literatos brasileiros, que língua usou, e por que muitos de seus livros fizeram tanto sucesso? A nossa hipótese é a de que

1 Cf. Pinto (s.d., p. 55-6): "Assim, partindo como sempre de seus usos, visto que se considera um legítimo representante da variante brasileira da língua portuguesa, e, portanto, credenciado a teorizar sobre ela, Alencar se empenha em estabelecer regras de uma nova gramática, baseada, de maneira mediata, no uso popular e, de maneira imediata no uso literário, pois depurar a 'língua inculta' do povo era, a seu ver, função do escritor." 
Alencar introduziu mais "o discurso brasileiro" em seus textos e não uma "língua brasileira", vale dizer, introduziu mais uma maneira de falar, ou uma prática enunciativa, e menos uma gramática brasileira. É o que tentaremos mostrar pelo exame da metalinguagem que o autor produziu ao longo de dez anos de polêmicas linguísticas.

As marcas de Alencar são o gosto pela polêmica e a contradição. Embora suas provocações e suas respostas sobre questões linguísticas sejam apaixonadas e façam parecer que o escritor tem plena convicção sobre o que afirma, suas opiniões ou posições nem sempre são coerentes, como veremos a seguir.

Alencar representa a era romântica. É um romântico, vive e morre como um romântico (de tuberculose, inclusive). C earense, foi para a capital do Império estudar, mas, ainda adolescente, mudou-se para São Paulo a fim de começar seu curso de Direito. Foi colega de tipos como Álvares de Azevedo, B ernardo G uimarães e Aureliano Lessa, todos jovens boêmios e agitadores da noite; Alencar, todavia, nunca se agregou nem a esse nem a nenhum outro grupo de estudantes. E ra distante e reservado. Isolado, sempre, sofria em São Paulo com o frio, a umidade e a solidão, por isso, e para ficar mais perto do pai que estava, então, no Ceará, mudou-se para Olinda depois de dois anos de sua estada em São Paulo, onde demorou pouco, um ano. C ontava nessa época dezenove anos, quando teve manifestados os primeiros sintomas da tuberculose que o atormentou vida afora. Resolveu, em razão da doença, voltar a São Paulo para terminar o curso, pois ficaria mais perto da família, mãe e irmãos, que moravam no Rio de J aneiro.

Alencar, segundo ele próprio conta no texto em que faz uma autodefinição, Como e porque sou romancista, diz que desde menino teve gosto pela literatura. Quando jovem escreveu alguns textos que deixou esquecidos na gaveta e, quando estava na faculdade, já pensava na literatura nacional. S en- 
tia-se frustrado porque o francês, clássico, que aprendera na escola não o possibilitava a ler "a obra monumental de B alzac". Mas, certa vez, um seu colega de faculdade, o carioca Francisco Otaviano de Almeida Rosa, emprestou- lhe o volume das obras completas de B alzac. Alencar, então, pôs-se a estudar aquele francês e não demorou a dominá-lo. E m oito dias leu a Grenadière, e em um mês deu conta de todo o volume de Balzac. Depois disso, percorreu muitos títulos da literatura francesa romântica e, como ele mesmo afirmou, leu "o que havia de Alexandre Dumas e Alfredo Vigny, além de muito Chateaubriand e Victor Hugo.”. (Lira Neto, 2006, p. 72)

Esse contato foi literariamente decisivo para Alencar. $\mathrm{O}$ "choque de língua" que tomou o fez logo imaginar que o mesmo processo deveria acontecer no B rasil. Lira Neto (id., p. 73) escreve sobre isso:

Foi uma revelação. Para Alencar, desde já, o grande desafio seria alguém escrever, em português, obras que representassem para o Brasil o que Balzac, Dumas, Chateaubriand e Hugo representavam para a França. E m outras palavras, inventar uma literatura com sabor nacional. No caso do Brasil, criar um estilo tropical.

Mas ainda era cedo para Alencar. E seguindo esse filão, no B rasil, apareceu J oaquim Manuel de Macedo que, em 1849 , publicou seu único romance, A moreninha. Esse foi talvez o primeiro livro de grande sucesso popular no B rasil, e os críticos atribuem o fato exatamente às suas características de romance romântico urbano brasileiro, além de ter sido, o que é mais importante, vazado em linguagem próxima à da realidade linguística do $\mathrm{B}$ rasil.

Ainda na faculdade, Alencar escreveu alguns ensaios que enviou à revista estudantil Ensaios Literá rios. E m seu segundo ensaio, publicado em 1849, com o título Sobre a vida de $d$. Antônio Felipe Camarão, narra fatos, colhidos na biblioteca de Olinda, da vida de um índio que participou das lutas con- 
tra os holandeses em Pernambuco. Nesse texto, diz Lira Neto (id., p. 83), Alencar manifesta sua indignação contra o massacre a que foram submetidos os índios brasileiros.

Foi em 1850, contudo, que escreveu um artigo em que, pela primeira vez, tratou de literatura. Já nesse artigo, intitulado $O$ estilo na literatura brasileira, defendia a ideia nascida da leitura dos românticos franceses: a literatura brasileira tem de refletir "a cor local". Assim, disse:

Nunca a dicção do estilo quinhentista poderia exprimir, com a doce facilidade do espírito, uma cena encantada de nossa terra, um suave retiro de nossas florestas, uma tarde pura de nosso céu, com esses tons maviosos, com esses timbres sonoros que lhe reflete o sol decaindo no ocidente. (Apud Lira Neto, p. 84)

Terminado o curso de Direito, Alencar foi morar no Rio de J aneiro. Informa-nos Lira Neto (op. cit. p. 88) que, imediatamente à sua chegada, de 1851 a 1854, trabalhou em um escritório de advocacia, como assistente. Depois, ainda em 1854, começou carreira como jornalista, contratado pelo Diário do Rio de Janeira como folhetinista. Escreveu quatro folhetins, intitulados Álbum publicados anonimamente aos domingos. O biógrafo de Alencar informa que esses textos são raríssimos, jamais foram publicados em suas coletâneas nem nas Obras completas. A linguagem aí praticada era coloquial, leve, próxima o quanto possível da prática linguística brasileira, para cativar os leitores.

Depois disso, deslanchou a carreira de jornalista de Alencar quando, ainda em 1854, assumiu o posto no Jornal doC ommércia como responsável pela coluna Aocorrer da pena e pela seção forense. Ali criou seu estilo - linguagem leve, contemporânea - e, também, inaugurou o gênero polêmicas linguísticas, a respeito do português do B rasil. A contemporaneidade da linguagem implicava o uso de termos franceses, o it do momento, em Portugal e no Brasil. Essa característica, 
inclusive, ensejou uma primeira polêmica linguística, no jornal. Um leitor incomodado com os galicismos de Alencar reclamou, coberto pelo pseudônimo Monsieur de Tal, por carta endereçada à seção do jornal Pergunta inocente, para a qual faz a seguinte indagação (op. cit., p. 114-115): "Vários jornais que falaram ontem do carnaval parecem muito desejosos de que fique entre nós nacionalizado o entrudo. (...) Mas não acham os senhores redatores que seria melhor primeiro nacionalizar a língua?". O mote para a polêmica estava dado. Alencar reagiu, indignado com a crítica, e fez afirmações que, lidas depois de se conhecer o teor de suas discussões linguísticas, posteriores a esse fato, revelam a ponta do iceberg de suas contradições. Assim é a reação do jornalista:

Mas que quer dizer nacionalizar a língua portuguesa? S erá misturá-la com a tupi? Ou será dizer em português aquilo que é intraduzível, e que tem cunho particular nas línguas estrangeiras? Mãos à obra. Daqui em diante, em vez de dizer passeei num coupé, se dirá andei num cortado. ${ }^{2}$ (...)

Quem não quiser por isso, pode agarrar-se à língua tupi, e achará nela uma mina ainda não explorada de imagens poéticas, uma multidão de nomes fanhos, de frutas, de coquinhos, de bichinhos, de cipós, que devem ser de uma originalidade encantadora. Teremos então cabelos de samambaia, lábios de uricuri, olhos de guajirú, et reliquia commitante caterva. ${ }^{3}$

Esse folhetim, todavia, não se encontra entre os demais publicados no livro Ao correr da pena; como disse Lira Neto, "foi providencialmente expurgado" (ib.). A partir daí, as polêmicas das quais Alencar tomou parte, como ação ou reação, foram incontáveis. Por isso, vamo-nos fixar naquelas em que o autor se restringiu a comentar ou a defender seus usos

2 Correio Mercantil, 21 de janeiro de 1885 (Apud Lira Neto, p. 115).

3 Correio Mercantil, 28 de janeiro de 1885 (Apud Lira Neto, p. 115). 
linguísticos, a partir de 1865, quando surdiu a segunda edição do romance Diva. A essa altura, Alencar já havia publicado em folhetins Cinco minutos, que depois saiu na forma de livro como brinde aos leitores do Diário do Rio de Janeira jornal do qual se tornara diretor, com a incumbência de reverter o marasmo financeiro e a pré-falência em que se encontrava a empresa. Publicar novelas folhetinescas populares foi a estratégia de Alencar. Nisso foi vitorioso porque o público reagiu muito bem à novela, publicada em oito capítulos. A reação favorável do público ficou clara porque as pessoas procuravam a redação do jornal para obter um volume do livro que havia sido distribuído gratuitamente aos leitores. Isso levou Alencar a publicar outra novela. Dessa vez, $O$ Guarani que, muito mais que a anterior, repercutiu favoravelmente, no país inteiro.

Por ocasião da publicação de Diva, Alencar já era escritor experiente. Havia também se dedicado ao teatro e já publicado outros três romances, os já citados e mais $A$ viuvinha e Lucíola (esse publicado sob o pseudônimo GM). As críticas sobre Diva foram muitas, mas o que levou J osé de Alencar à reação foram as linguísticas. Fora acusado de empregar muitos estrangeirismos e de "estropiar a língua portuguesa". Isso o levou a inaugurar a prática de agregar aos romances suas defesas linguísticas. Por duas vezes, assim procedeu, por reação à crítica, e redigiu posfácios aos romances Diva e Iracema. C omo ação, visando a responder preventivamente a possíveis críticas, escreveu Bênção Paterna, prefácio ao livro Sonhos d'Ouro Seu pensamento sobre a língua aparece também em outros textos, por exemplo, nas polêmicas que travou com: J oaquim Nabuco, pelo jornal $O$ Globo durante dois meses, em uma coluna que intitulou Às quintas, uma referência ao dia em que respondia ao seu contendor, que escrevia Aos domingos; J oaquim Serra, por cartas, depois publicadas no livro NossoCancioneira Pinheiro Chagas e Antônio Henriques Leal, publicados no livro Iracema, edição de 1965, p. 218-240. E sse conjunto constitui o corpus que iremos examinar. 


\section{O LUGAR DE ONDE FAlA AlENCAR}

A formação discursiva de Alencar foi romântica. Ele se fez do encantamento e admiração dos românticos estrangeiros ingleses e franceses. Uma crítica que sempre lhe imputaram, a qual não deu ressonância, foi aquela a respeito do decalque de estruturas de romances estrangeiros. Nabuco, por exemplo, reafirmou a crítica que então se fazia sobre o fato de $O$ Guarani ser plágio dos romances indianistas de $\mathrm{C}$ hateaubriand e, ainda teceu críticas novas sobre a fragilidade especialmente de C ecília.

D o romantismo, portanto, vieram a afirmação da nacionalidade e a prática da linguagem mais próxima da realidade linguística brasileira. Quanto a essa característica, vimos acima como, efetivamente, o autor se inspirou especialmente nos românticos franceses. O que se pode dizer, certamente, é que Alencar praticava naturalmente em seus textos essa linguagem leve e mais informal, ou pelo menos diferente da linguagem portuguesa quinhentista que se praticava no B rasil e que nem em Portugal tinha mais vigor. Sobre essa questão voltaremos adiante.

O nacionalismo de Alencar era baseado em dois pilares: a valorização da natureza brasileira e o aproveitamento da contribuição linguística indigenista. De passagem, o autor se refere a outras contribuições, como a africana e a devida à imigração estrangeira. O que é fato é a ligação direta que Alencar faz entre língua e pátria, como aparece logo no início do Poscrito a Diva, "A língua é a nacionalidade do pensamento como a pátria é a nacionalidade do povo”. A literatura, e não somente a língua, segundo J osé de Alencar, tem de ser o espelho da nacionalidade. Isso ele afirma em Bênção paterna ${ }^{5}$, num diálogo simulado com o livro, para antecipar as de-

Apud Pinto (1 978).

5 Apud Pinto (1978). 
fesas que poderiam vir dos críticos. Nesse texto, Alencar propõe uma periodização da literatura brasileira em três fases primitiva, histórica, política - todas preenchidas (iniciadas e limitadas) com e por suas obras. A reflexão sobre o nacionalismo dessa literatura, que é expressada em discurso direto, entre aspas, cria o efeito da realidade das palavras do autor que "sussura":

A literatura nacional que outra cousa é senão a alma da pátria, que transmigrou para este solo virgem com uma raça ilustre, aqui impregnou-se da seiva americana desta terra que lhe serviu de regaço: e cada dia se enriquece ao contacto de outros povos ao influxo da civilização? (B ênção, 91)

A respeito da influência que as raças indígenas exerceriam sobre a língua praticada no Brasil afirmou:

Cumpre não esquecer que o filho do Novo Mundo recebe as tradições das raças indígenas e vive ao contato de quase todas as raças civilizadas e suas plagas trazidas pela emigração. (Iracema, 76)

Sobre a influência indígena no português afirmou, também, que faltava um estudo minucioso para definir-lhe o contorno e a extensão. Mesmo assim, transcreve, concordando, um trecho do Ensaio de antropologia, de C outo de Magalhães, que relata haver, na linguagem brasileira das províncias do Pará, G oiás e do Mato G rosso, não somente vocábulos indígenas mas também 'frases, figuras, idiotismos e construções peculiares ao tupi'.

Essa ideologia da diferença reflete-se, embora claudicantemente, na denominação que o escritor tenta dar à língua portuguesa do B rasil. D enominá-la "língua portuguesa" pelo menos no mesmo texto, Pós-escrito a Iracema, em que fez a afirmação transcrita acima seria incoerência demais. Por isso, preferiu aí usar a expressão dialeto como se vê a seguir: 
O B rasil já está nestas condições, a influência nacional já se faz sentir na pronúncia muito suave do nosso dialeto. (Iracema, 77)

Outras denominações, porém, inclusive língua portuguesa, aparecem nos comentários de Alencar, conforme já havia registrado Pinto (op. cit, p. XXIV): dialeto brasileiro, em face de um dialeto português, quando, portanto, os termos dialeto e língua são equivalentes; português (...) novo idioma; nosso português americano e o português europeu; língua portuguesa. O autor usa, também, o termo dialeto na acepção de "língua vulgar do povo", num sentido próximo ao que hoje daríamos à variedade social popular.

O lugar a partir do qual Alencar fala é o do escritor. Essa opção fica muito clara em seu discurso, porque as relações escritor x público e escritor x língua são o ponto mais consistente de sua discussão. Desse campo saem também algumas afirmações um pouco mais firmes sobre língua e suas diferentes realizações e sobre o papel do escritor na seleção do registro adequado ao texto literário.

Ao escritor, diz ele, cabe trabalhar com uma linguagem que reflita a realidade do povo que a pratica. Assim, rejeita, e essa é uma opinião firme e constante, a ideia de que a literatura tenha de ser talhada em linguagem arcaizante, em benefício da manutenção da origem clássica da língua. O outro extremo, a reprodução cega, na literatura, da realidade linguística também não é cabível. D esse paradoxo, então, sugere Alencar, nasce a importância do escritor, que é, como ele diz, um mediador entre o antigo e o novo. Nesse sentido, afirma:

A linguagem literária, escolhida, limada e grave, não é por certo a linguagem sediça e comum que se fala diariamente e basta para a rápida permuta das ideias: a primeira é uma arte, a segunda é simples mister. Mas essa diferença se dá unicamente na forma da expressão, na substância a linguagem há de ser a mesma, para que o escritor possa 
exprimir as ideias de seu tempo, e o público possa compreender o livro que se lhe oferece. (Diva, 56) (Grifamos)

Essa passagem é, no que se refere à teorização da linguagem por parte do autor, uma das mais felizes. Aqui ficam diferenciadas a linguagem literária, que é arte, e a linguagem corrente, que é atividade, necessidade. Também o reconhecimento, e até a formulação dos conceitos, dos planos da expressão e do conteúdo explicam sua prática discursiva e definem o motivo do sucesso de seus textos, não somente os literários mas também os jornalísticos. O argumento mais forte de Alencar em defesa de sua tese contra o passadismo da língua praticado na literatura, ou na escrita, já que o mesmo estilo era adotado nos textos jornalísticos, por exemplo, foi mais "estético-nacionalista", na expressão de Pinto (op., cit., p. XXVIII), que gramatical. E ra do lugar de escritor que sua voz era mais firme. Como crítico da língua, seus argumentos foram fracos e confusos. Os pormenores ortográficos e gramaticais discutidos não caracterizavam a linguagem brasileira nem contribuíam para o sucesso (ou o insucesso) de seus romances.

A interação escritor / público foi outro ponto sobre o qual demonstrou lucidez. Seu ponto de partida para o desenvolvimento desse tema é a recriminação à importância que "a escola clássica” atribui ao escritor. Alencar reconhece que não é o escritor que a detém e que, portanto, a constroi. Ele não hesita em afirmar que os bons escritores operam artisticamente sobre a língua e podem usar termos antigos, que buscam nos textos tradicionais, ou mesmos novos, que criam a partir das possibilidades da língua, mas sua inspiração vem da linguagem do público. Entende, portanto, que entre escritor e leitor tem de haver interação constante. Num diálogo com a teoria naturalista, assim resume seu pensamento sobre a questão: 
E m conclusão, o público e o leitor exercem uma influência recíproca: e essa lei moral tem um exemplo muito frisante em um fenômeno físico. A atmosfera atrai os átomos que sobem das águas estagnadas pela evaporação, e depois os esparze sobre a terra em puro cristalino rocio. São da mesma forma as belezas literárias dos bons livros: o escritor as inspira do público, e as depura de sua vulgaridade. (Diva, p. 58)

A análise de Alencar sobre o circuito interacional escritor/ público foi completa. C omo diz B akhtin (1 992), à interação é inerente a atitude responsiva a tiva dos interactantes, portanto, o escritor escreve, o público responde de algum modo e o escritor, por sua vez reage a essa reação. Isso, evidentemente não nesses termos, Alencar percebeu e comentou. D isse ele que ao público cabe a sanção, o desprezo ou o aplauso, sobre a literatura apresentada:

Não há contestar: é o direito da inspiração e do gosto, exerça-se ele sobre a ideia ou sobre a palavra. Ao público cabe a sanção: ele desprezará o autor que abuse da língua e a trucide, como despreza aquele que é arrastado às monstruosidades e aleijões do pensamento. $\mathrm{Da}$ mesma forma aplaudirá as ousadias felizes da linguagem, como aplaude as harmonias originais e os arrojos do pincel inspirado. (Diva, 59)

Como ressaltou Pinto (op. cit, p. XXVI), Alencar diferenciou-se de seus pares neste quesita "a profunda consciência da missão específica do artista ante o instrumento artesanal que é a lingua”.

\section{Conceito DE LÍNGUA}

Já no terreno da língua e da gramática Alencar não foi tão feliz Suas opiniões são impressionistas e confusas, quando não contraditórias. C omo já ressaltaram Pinto (op. cit.) e 
Leite (1 999), Alencar não conseguiu defender uma tese ampla sobre a língua portuguesa do Brasil, embora aparentemente esse fosse o tema da discussão. Todos os esforços que envidou em defesa do que parecia ser da língua do Brasil foram, em verdade, em defesa de usos pessoais. Também, essas defesas não apareceram relacionadas com o que enunciara sobre o escritor e seu papel diante da língua e da literatura. A cada polêmica, formulava argumentos que não se coadunavam, ou que não mostravam coerência conceitual sobre os temas fundamentais a respeito do que discutia: língua, uso, dialeto, gramática.

O maior conflito nasceu da miscelânea teórica que o autor fez quando tratou de língua. S eu ponto de partida conceitual pareceu ser humboldiano, mas como a fonte que suporta a definição não foi declarada, não se pode afirmar se Alencar tinha ou não consciência sobre o que afirmava, embora tudo leve a crer que não tinha. Para Humbold", "a linguagem, que é uma criação contínua e só existe como manifestação do espírito humano, é energeia e não ergon; é o órgão criador do espírito humano". Humbold acreditava, também, que "a forma interna da linguagem (innere $S$ prachform) é um constituinte fundamental do espírito humano e que cada forma da linguagem pode ser considerada como caracterização do povo que a fala". Pois Alencar diz:

E ntende [o autor deste volume] que sendo a língua instrumento do espírito não pode ficar estacionária quando este se desenvolve.

(...)

Não é obrigando-a a estacionar que hão de manter e polir as qualidades que porventura ornem uma língua qualquer: mas sim fazendo que acompanhe o progresso das ideias e se molde às novas tendências do espírito sem contudo perverter sua índole e abastardar-se.

6 Apud Leroy, (1987, p. 49). 
(...)

Quanto à frase ou estilo, também não se pode imobilizar quando o espírito, de que ela é a expressão, varia com os séculos de aspirações e hábitos.

(Diva, 55-6)

Depois, no pós- escrito a Iracema, ainda retomou essa ideia, para combater a opinião do crítico português Pinheiro Chagas, que, esteado na teoria naturalista, por Max Muller, afirmara ser "a Filologia uma ciência natural, regida por leis invariáveis como a rotação dos astros”. Primeiro, há a apresentação do argumento de que é o povo que tem o poder de transformar a língua, pelo uso, pelo costume; depois, a reafirmação da ligação linguagem/ espírito e que, por isso, o escritor não poderia interferir no sentido de alterar a língua. Nesse sentido diz

A linguagem, porém, a única das artes que fala ao espírito, é um marco imutável, sobre o qual nenhuma ação têm os escritores, esses obreiros da palavra, que a nova teoria reduz à condição de mecânicos, mais ou menos destros no manejo de um instrumento bruto! (Iracema, 74)

Nega, pois, a teoria naturalista. Alencar, contudo, contradiz-se imediatamente, quando, para dizer que Pinheiro Chagas entendeu mal a teoria de Max Muller, voltou a falar da atuação do povo no sentido de alterar a língua e, também, da atuação do escritor sobre a língua, no sentido de "aperfeiçoá-la". E assim, manifestou-se, na sequência do trecho anteriormente transcrito.

Suponho eu que há grande equivocação na interpretação dada à teoria de Max Muller. O corpo de uma língua, a sua substância material, que se compõe de sons e vozes peculiares, esta só a pode modificar a soberania do povo, que nesses assuntos legisla diretamente pelo uso. Entretanto, mesmo nesta parte física é infalível a influencia dos bons 
escritores: eles talham e pulem o grosseiro dialeto do vulgo, como o escultor cinzela o rudo troço de mármore e dele extrai o fino lavor. (Iracema, 74)

O pior não é essa "pequena" contradição, porque, de qualquer forma, a crença na atuação do escritor relativamente à construção da linguagem literária, a partir do aproveitamento e recriação da linguagem comum, é a premissa do autor. Aqui foi esquisita a primeira negação.

Muito contraditória é a afirmação, por demais conhecida e repetida, que encerra o comentário BênçãoPaterna. Nesse caso, como se verá, a teoria naturalista foi completamente absorvida. No trecho a seguir, o que se vê é uma confusão só: primeiro Alencar põe no mesmo caldeirão teórico J acob G rimm e Max Muller. Ora, os neogramáticos não comungavam as ideias de Schleicher nem de seu seguidor Max Muller, opunham-se às ideias naturalistas e, ao contrário delas, entendiam que as línguas eram produto coletivo, e o método que empregavam na análise das línguas era totalmente positivista, até referido como "leis fonéticas" 7 . Além disso, Alencar apresenta uma proposta, quase "teórica", completamente fundada no princípio naturalista, por Max Muller, quando se manifesta, negando tudo que antes dissera:

Estando provado pelas sábias e profundas investigações começadas por Jacob Grimm e ultimamente desenvolvidas por Max Muller, a respeito da apofonia, que a transformação mecânica das línguas se opera pela modificação dos órgãos da fala, pergunto eu, e não se riam, que é mui séria a questão:

O povo que chupa o caju, a manga, o cambucá e a jabuticaba, pode falar uma língua com igual pronúncia e o mesmo espírito do povo que sorve o figa a pêra, o damasco e na nêspera? (B ênçao, 96)

7 Cf. Leroy, p. 54. 
Alencar tem razão quando diz que as pesquisas sobre a evolução fonética havia começado com $\mathrm{G}$ rimm e continuado com Max Muller (depois de S chleicher), mas as bases teóricas sobre as quais os trabalhos desses investigadores se desenvolveram eram diferentes, pois os neogramáticos se "opunham à concepção schleicheriana da linguagem como organismo natural, [e] consideravam a língua, pelo contrário, um produto coletivo dos grupos humanos" Alencar insiste no caráter naturalista das leis fonéticas e da filiação naturalista de $\mathrm{G}$ rimm. Ao responder a Nabuco, exatamente sobre a crítica à "brincadeira" do parágrafo acima reproduzido, esse argumento é usado inclusive com alguma arrogância:

O crítico nunca ouviu falar das leis fonéticas de Grimm: senão compreenderia o remoque do meu prólogo aos Sonhos de Ouro.

O grande filólogo a lemão demonstrou que o clima e com este as condições peculiares à vida de um povo, influindo no organismo, necessariamente, modifica vam os órgãos da voz; e dessa modificação resultavam as alterações fonéticas de uma língua transportada a outra região diversa daquela onde teve origem. (Quintas, 141)

Depois disso, recorreu também a Muller, para justificar a evolução da língua. Sobre o fato da diferença do português do B rasil, escreveu a J oaquim S erra, de quem se disse amigo, para explicar por que o português do B rasil, que ele denominou, nessa carta, dialeto brasileiro, não era mais o mesmo de Portugal. Aqui todos os argumentos naturalistas eram conve nientes: influência do meio, do clima, de outras raças etc. É assim que fala em progresso, alinhado às teses de $\mathrm{S}$ pencer, e, então, já completamente de acordo com Max Muller, comparou a língua à natureza, afirmação indireta na pergunta que formulou, como se poder ler a seguir.

8 Idem. 
A transformação contínua que se opera na história filológica e que Muller compara à vegetaçãa cessou de todo para o português de que se pretende fazer uma múmia clássica? (sic) (Cancioneiro, 126)

A resposta à pergunta auto-endereçada fecha o raciocínio naturalista:

As línguas, como todo o instrumento da atividade humana, obedecem à lei providencial do progressa não podem parar definitivamente. (ib.)

Em meio à relação língua/natureza há também a relação língua/costume. No mesmo texto em que assume a tese naturalista, mistura a tese sociológica. Essa parece apenas intuitiva, já que não chama nenhum teórico para apoiar sua afirmação. O argumento do autor em favor do costume é diluído com a ideia de gosto. Talvez aqui haja também um fundo de determinismo social: gostamos daquilo de que todos gostam. Assim defende a diferença do português do Brasil frente ao de Portugal:

A manga, da primeira vez que a prova, acha-lhe o estrangeiro gosto de terebentina: depois de habituado, regula-se com o sabor delicioso. Assim acontece com os poucos livros realmente brasileiros: o paladar português sente neles um travo; mas se aqui vivem conosco, sob o mesmo clima, atraídos pelo costume da família e da pátria irmãs (sic), logo ressoam docemente aos ouvidos lusos os nossos idiotismos brasileiros, que dantes lhes destoavam a ponto de os ter em conta de senões. (Bênção, 95)

Mas a língua como costume, no sentido de uso, sempre foi evocada por Alencar. Desde seus primeiros textos, dizia, como já mostramos antes quando falamos do pensamento de Alencar sobre o papel do escritor, que o povo é que tem o poder de alterar a língua pelo uso que dela faz. Por isso disse, 
ao retrucar aquela crítica que Pinheiro Chagas formulou com base em argumento naturalista, que "só o povo tem a força de transformar uma língua, modificar sua índole” (p. 74). Outra afirmação, porém, foi ainda mais incisiva, quando mais uma vez falava do uso e do papel do escritor. Esse trecho, inclusive, foi motivo de uma crítica por parte de Antônio Henriques Leal, brasileiro, do Maranhão, que morava em Portugal. Mas é preciso registrar que o crítico maranhense deturpou o sentido da frase, porque não considerou exatamente o que Alencar afirmou sobre a atuação do povo na criação de novos termos. O trecho em questão é o seguinte:

Antes de tudo uma observação. Desde que uma palavra for introduzida na língua por iniciativa de um escritor ou pelo uso geral, entendo eu que torna-se nacional como qualquer outra e sujeita-se a todas as modalidades do idioma que a adotou: portanto, pode ela, como qualquer vocábulo originário, ser empregada nos vários sentidos figurados a que se apresente com propriedade e elegância. (Iracema, 80)

Para encerrar esse tópico, vamos nos arriscar a recuperar alguns argumentos de Alencar que indicam, de certa maneira, o reconhecimento de que a língua se organizava como um sistema. Quando o autor diz da possibilidade de o povo e o escritor criarem termos para nomear as novidades americanas, "sem abastardar e perverter a índole" da língua, parece ter pensado numa arrumação própria da língua, que, em linguagem atual, seria dita como organização sistêmica. Ao defender todos os seus neologismos e galicismos, também, é à potencialidade e à possibilidade que a língua oferece para que se criem novas palavras que o escritor recorre. Quando defende a palavra "garrular" diz "Da propriedade que tem nossa língua de criar novos vocábulos já falou o autor de Gênio da língua portuguesa (Leoni). Facilmente se adapta uma desinência verbal a qualquer nome, verbo.". Do mesmo modo, quando se refere à variação temporal da frase, e aí inclui o estilo, fala do gênio da língua, o que é, igualmente, equivalen- 
te à ideia de sistema. Esses conceitos encontram-se nos seguintes trechos:

Não é obrigando-a [a língua] a estacionar que hão de manter e polir as qualidades que porventura ornem uma língua qualquer: mas sim fazendo que acompanhe o progresso das ideias e se molde às novas tendências do espírito, sem contudo perverter sua índole e abastardar-se. (Diva, 55)

Criar termos necessários para exprimir os inventos recentes, assimilar-se aqueles que, embora oriundos de línguas diversas, sejam indispensáveis, e sobretudo explorar as próprias fontes, veios preciosos onde talvez ficaram esquecidas muitas pedras finas: essa é a missão das línguas cultas e seu verdadeiro classismo. (Diva, 56)

Quanto à frase ou estilos, também não se pode imobilizar quando o espírito, de que ela é expressão varia com os séculos de aspirações e hábitos. (...) devemas línguas aceitar novas maneiras de dizer, graciosas e elegantes, que não repugnem o seu gênio e organisma (Ib.)

Tudo o que até aqui foi dito é suficiente para mostrar que Alencar não tinha convicção sobre as propriedades e a natureza da língua. Falava por intuição. Por isso, não conseguiu conceituar precisamente seu objeto de análise e claudicou no assunto. No fim, não é possível, pela leitura de sua produção metalinguística, chegar a um conceito de língua com o qual operou. Muitos são os conceitos que pululam em seus textos, simultaneamente, mesmo sendo incompativeis entre si. Para resumir a situação, apresentamos alguns deles, pressupostos nos argumentos que o autor formula para defender-se:
Natureza argumento do Conceito de língua
Psicológica
A língua é um instrumento do espírito Sociológica A língua é produto social, de uso geral do pova É a expressão de fatos morais e sociais. 
Política

Naturalista

Literária

Linguística

Pragmática
A língua é a expressão da nacionalidade. A língua é um organismo vivo que se transforma por influência do a mbiente, do clima e da ação da física nos órgãos fonadores.

A língua é arte.

A língua é possibilidade de realização de palavras e organização da frase (gênio e organis mo).

A língua é mis ter.

Uma última reflexão sobre esse ponto. A língua, segundo o autor, progride, evolui. Isso é tema do primeiro parágrafo do Pos crito (Diva): "O autor desse volume e do que o precedeu com o título Lucíola sente a necessidade de confessar um pecado seu: gosta de progresso em tudo, até mesmo na língua que fala.". A palavra progress o aqui não tem o sentido naturalista, mas sociológico. Esse é, então, um manifesto sociológico de Alencar. O argumento usado para defendê-lo é o de que a língua progride porque acompanha o desenvolvimento social: a criação de inventos, a expressão de novas ideias etc.

A palavra progresso é empregada, também, como acima mostramos, no sentido naturalista. Quer dizer, nesse caso, a língua nasce e progride sob certas condições climáticas, ambientais e físicas, como diz na seguinte passagem:

Se o português, transferindo-se para a América, desenvolvendo-se no seio de uma natureza tão opulenta como aquela onde se enriqueceu o sânscrito seu antepassado: se o português nessas condições não tivesse o viço e a seiva necessários para brotar de si um novo idioma sonoro, exuberante e vigoroso, triste dele: seria uma língua exausta, votada a breve e rápida extinção. (Cancioneiro, 127)

Em que consiste "a transformação profunda [por que passa o] idioma de Portugal no Brasil”, como declarou o au- 
tor? Resposta afirmativa não deu, mas vemos diluída pelos textos, a ideia de que serão as mesmas transformações que foram operadas nas línguas românicas a partir do latim. Quer por ação da natureza, quer por ação social.

\section{CONCEITO DE GRAMÁTICA}

Poder-se-ia pensar que o conceito mais perceptível de Alencar, sobre gramática, fosse o da tradicional. Isso, contudo, não se confirma porque o autor, embora consulte gramáticas e cite seus autores (S otero dos Reis, Gramática da língua portuguesa; Madvig, Gramática latina), subverte as regras e propõe algumas que, em seu entender, seriam mais coerentes com a natureza da língua portuguesa. Além, disso, percebe-se, subliminar às suas afirmações sobre o papel do escritor, como vimos, a tarefa de fazer uma gramática a partir da linguagem "do vulgo ignorante". Isso significa, como veremos a seguir, que reconhece a existência da gramática natural, inerente à língua correntemente praticada. Nesse caso os conceitos de gramática e língua se confundem. Esclareça-se, contudo, que Alencar atribui um valor negativo a essa gramática, que passará a ser valorizada positivamente depois da operação do escritor. Observe-se, no excerto exposto a seguir a seguinte afirmação: "O mesmo sucede com a gramática: saída da infância do povo, rude e incoerente, são os escritores que a vão corrigindo e limando".

Alencar, ao se defender das críticas de Pinheiro Chagas, fala da gramática como filosofia e como ciência. Nesse caso, entende que a língua tem uma materialidade fonética, que lhe forma o corpo, a que corresponde uma parte lógica. A união desses dois aspectos forma a gramática. Nesse caso,

opera com o conceito psicológico de língua, e diz que esse lado lógico é o espírito da língua. Mas a gramática é também uma filosofia: a filosofia da palavra. O que queria dizer com isso, porém, não declarou. Por fim, a gramática é ciência, mas 
a explicação que dá para esse fato não é coerente com o conceito de ciência. Afinal, a formulação é tão confusa que é impossível ser dissecada. Somente a leitura do trecho completo permite que se tenha ideia da situação a que nos referimos. $\mathrm{O}$ trecho é longo, mas tem de ser inteiramente reproduzido pois sua falta de clareza não admite cortes:

Mas além dessa parte fonética da língua, que forma seu corpo, há a parte lógica, o seu espírito, ou para usar a terminologia da ciência, a gramática. Essa não é, como se pretende, mera rotina ou usança confiada à ignorância do vulgo, que somente a pode alterar. Aqui está o ponto fraco da teoria invocada . ${ }^{9}$

A gramática, ou a filosofia da palavra, é incontestavelmente uma ciência. Como todas as ciências, ela deve ter em cada raça e em cada povo um período rudimentário: ainda mesmo depois de largo desenvolvimento, existirá algum ramo de conhecimentos humanos que não esteja imbuído de falsas noções e até de erros crassos?

O mesmo sucede com a gramática: saída da infância do povo, rude e incoerente, são os escritores que a vão corrigindo e limando. Cotejem-se as regras atuais das línguas modernas com as regras que predominavam no período da formação dessas línguas, e se conhecerá a transformação por que passaram sob a ação dos poetas prosadores. (Iracema, p. 74) ${ }^{10}$

Desse amontoado de ideias é difícil fazer uma formulação única porque os termos são incompatíveis. Então, a saída é dizer que Alencar não tem clara formulação sobre o conceito de gramática e, pois, ao mesmo tempo, a gramática é: lógica, filosofia, ciência e a própria língua, uso (gramática natural). As teses que Alencar conseguiu formular e sustentar metalinguisticamente, até o fim foram duas: a do papel do escritor na construção da língua literária; e a do passadismo da língua literária que se praticava então.

\footnotetext{
9 O naturalismo de Max Muller, citado por Pinheiro Chagas.

10 Apud Pinto (1978).
} 
No mesmo texto (p. 73), Alencar diz que suas opiniões a respeito de gramática têm-lhe valido a pecha de inovador ou de escritor incorreto e descuidado. Isso, contudo, não se refere aos conceitos aqui já comentados, mas ao de gramática tradicional. Antes dessa afirmação ele se explica sobre falhas tipográficas e sobre alguns de seus usos, considerados incorretos pelos críticos. Nesse caso, o que se vê não é uma defesa dos erros cometidos por descuido ou pelo aproveitamento de usos populares na literatura. Não. São defesas de algumas regras que o autor criou para seu uso. Muitas vezes são regras ortográficas que Alencar modificou, por não concordar com a convenção vigente. Outras vezes são regras gramaticais que ele cria e justifica com argumentos diversos, desde a fidelidade ao latim e ao português clássico, até preferência pessoal. Vejamos alguns desses problemas e suas justificativas:

\begin{tabular}{|c|c|}
\hline $\begin{array}{c}\text { Natureza do fato } \\
\text { criticado: ortográfica }\end{array}$ & \multicolumn{1}{c|}{ Justificativa } \\
\hline $1^{\circ}$ grafia -ão/am. & $\begin{array}{l}\text { Opção por -am, por } \\
\text { afinidade etimológica. Na } \\
\text { edição aparecem } \\
\text { simultaneamente as duas } \\
\text { formas. Critério para } \\
\text { escolha da forma: } \\
\text { "quantidade da sílaba e não } \\
\text { natureza da palavra". } \\
\text { Exemplos: vazão/ } \\
\text { vazam Se o som nasal for } \\
\text { breve deve optar-se por - } \\
\text { am, se for longo, por -ão. }\end{array}$ \\
\hline $2^{\circ}$ Grafia do à: & $\begin{array}{l}\text { Inconformidade com a } \\
\text { regra do acento grave na } \\
\text { contração do artigo com a } \\
\text { preposição. Regra } \\
\text { particular: "É portanto } \\
\text { minha regra acentuar a }\end{array}$ \\
\hline
\end{tabular}




\begin{tabular}{|c|c|}
\hline $2^{\circ} \mathrm{Grafia}$ do à: & $\begin{array}{l}\text { Inconformidade com a } \\
\text { regra do acento grave na } \\
\text { contração do artigo com a } \\
\text { preposição. Regra } \\
\text { particular: "É portanto } \\
\text { minha regra acentuar a } \\
\text { prepos ição à sempre que ela } \\
\text { entra no dis curso isolado de } \\
\text { qualquer outra partícula: } \\
\text { seja embora seguida de } \\
\text { nome masculino, de verbo } \\
\text { ou pronome pessoal. Só } \\
\text { quando essa preposição } \\
\text { adere a ou outra palavra, } \\
\text { como por exemplo - ao, } \\
\text { torna-se inútil o sinal } \\
\text { ortográfico". } \\
\text { • } \rightarrow \text { Português: dialeto } \\
\text { derivado da língua romana. } \\
\text { • } \rightarrow \text { argumento } \\
\text { comparatista sobre o uso do } \\
\text { acento grave, para justificar } \\
\text { sua opção: } \\
\text { a) no francês } \\
\text { b) no italiano } \\
\text { c) no espanhol } \\
\text { Indagação sobre o } \\
\text { motivo do uso do acento } \\
\text { grave: evitar ambiguidade? } \\
\text { Indicar a contração do } \\
\text { artigo? Sugestão: se for esse } \\
\text { último o caso, deveria ser } \\
\text { usado o apóstrofo. } \\
\text { Observação final: No } \\
\text { livro, há ambos os casos. }\end{array}$ \\
\hline $3^{\circ} \mathrm{G}$ rafia dos ditongos. & $\begin{array}{l}\text { a) - eo / - eu. } \\
\text { Preferência de Alencar: } \\
\quad \text { - eo: desinência aberta } \\
\text { (chapeo, boleo, aspeo) } \\
\text { - eu: desinência } \\
\text { fechada (meu, perdeu, deus, } \\
\text { ateu) }\end{array}$ \\
\hline
\end{tabular}




\begin{tabular}{|c|c|}
\hline & $\begin{array}{l}\text { b) - iu / - ic } \\
\text { - ia para ditongo } \\
\text { imperfeito, que a rigor } \\
\text { constitui duas silabas, } \\
\text { como ria, fria alvedria } \\
\text {-iu. para o verdadeiro } \\
\text { ditongo: riu, feriu. }\end{array}$ \\
\hline $\begin{array}{l}4^{\circ} \text { Grafia da conjunção } \\
\text { se por si. }\end{array}$ & $\begin{array}{l}\text { fidelidade à etimologia } \\
\text { (latina). } \\
\text { - discriminação da } \\
\text { conjunção do pronome } \\
\text { pessoal (não importa a } \\
\text { homografia com os } \\
\text { pronomes que vêm } \\
\text { antecedidos / regidos de } \\
\text { preposição) se ( a si, de si, } \\
\text { por si, etc.) }\end{array}$ \\
\hline
\end{tabular}

O autor não formulou os problemas acima comentados para responder à crítica de um determinado contendor, mas para refutar críticas dispersas que recebeu depois da publicação da primeira edição de Iracema. No mesmo texto, há, contudo, aquelas respostas diretamente endereçadas a Pinheiro Chagas, já tantas vezes evocadas aqui. Como as críticas de Chagas basearam-se também no argumento gramatical, de caráter tradicional, Alencar obrigou-se a fazer uma incursão por esse território, o que não era, decididamente, seu forte. No quadro abaixo, apresentaremos, resumidos, os temas trazidos à luz, assim como os principais argumentos que o autor escolheu para defender-se.

\begin{tabular}{|c|l|}
\hline $\begin{array}{c}\text { Natureza do fato } \\
\text { criticado: gramatical }\end{array}$ & \multicolumn{1}{|c|}{ J ustificativa } \\
\hline Emprego do artigo definido & $\begin{array}{l}\text { Parcimônia no uso, só } \\
\text { empregado quando exigido } \\
\text { pela clareza ou estilo. } \\
\text { Argumento: o latim não } \\
\text { tinha artigo, sua omissão, } \\
\text { portanto, antes de ser } \\
\text { galicismo é um latinismo. } \\
\text { Clássicos omitiam artigo. }\end{array}$ \\
\hline
\end{tabular}




\begin{tabular}{|c|c|}
\hline $\begin{array}{l}\text { Verbos reflexivos sem o } \\
\text { pronome se (recolher, } \\
\text { enroscar, destacar). }\end{array}$ & $\begin{array}{l}\text { Argumentos: } \\
\text { Uso clássico: } \\
\text { recolher (J oão de Barros, } \\
\text { Clarimundo) } \\
\text { Estilo: concisão e } \\
\text { simplicidade } \\
\text { Gramática: verbos } \\
\text { figurativamente neutros } \\
\text { têm atributos distintos e } \\
\text { outras relações íntimas } \\
\text { com atributo. Como ocorre } \\
\text { no latim, logo o uso não é } \\
\text { neológico, mas arcaico. }\end{array}$ \\
\hline Colocação dos pronomes. & $\begin{array}{l}\text { Regra é a clareza e } \\
\text { elegância, eufonia e } \\
\text { fidelidade na reprodução } \\
\text { do pensamento. } \\
\text { Sobre a regra tradicional: } \\
\text { "tal regra não passa do } \\
\text { arbítrio que sem } \\
\text { fundamento algum se } \\
\text { arrogam certos } \\
\text { gramáticos." } \\
\text { Em latim, coloca-se ao } \\
\text { gosto do escritor e } \\
\text { segundo o estilo e clareza. } \\
\text { Usos variados nos } \\
\text { clássicos. }\end{array}$ \\
\hline Galicismos (inovações). & $\begin{array}{l}\text { Princípio: "Desde que uma } \\
\text { palavra... elegância." } \\
\text { Repúdio ao estrangeirismo } \\
\text { só deve ser aceito quando: } \\
1^{\circ} \text { a nova acepção é } \\
\text { um idiotismo da língua } \\
\text { estrangeira e se afasta do } \\
\text { sentido usual da palavra, } \\
\text { como tra ta mento do } \\
\text { emprego por es tipêndio; }\end{array}$ \\
\hline
\end{tabular}




\begin{tabular}{|l|l|}
\hline $2^{\circ}$ a palavra só foi \\
adotada em uma acepção \\
peculiar, como verdadeiro \\
idiotismo, como endossar \\
a letra. Seria inadmissível \\
ampliar o uso do vocábulo \\
e aplicá-lo em outro \\
sentido, como endossar o \\
casaco, da frase endossar \\
lhabit. flanco abandonar; \\
Brusco; flançar. \\
emoção.
\end{tabular}

Outras respostas, no mesmo diapasão, foram dirigidas ao brasileiro Antônio Henriques Leal, que criticou o "estilo frouxo e desleixado" de Alencar, no livro O Guarani. O crítico referiu-se ao estilo, especificamente no que se refere à coesão das frases pelos conectores, abundantemente usados pelos clássicos e escassos nos textos de Alencar. Essa foi, segundo entendemos, a resposta mais coerente que o escritor dirigiu a um contendor. Nesse caso, Alencar, articulou os campos do estilo e da gramática e, aí, pôde mostrar um pouco como o discurso atualizado pelo brasileiro, em português, causa estranhamento aos portugueses e aos brasileiros mais conservadores.

Alencar observou que o estilo do período clássico, carregado de conjunções, dificulta a leitura rápida e compreensiva do texto. Por isso, preferia escrever usando períodos, sob essa perspectiva, mais enxutos. A simplificação, dizia, recuperando o conceito de língua como expressão do pensamento, torna a frase "mais flexível para moldar-se a todos os relevos do pensamento". Para ilustrar seu ponto de vista, o autor trabalhou um período/parágrafo do português clássico, de Fr. Luís de Sousa, alterando seu estilo de clássico para moderno, e 
um trecho de O Guarani, fazendo o inverso, para mostrar, de um lado, a diferença de estilo e, de outro, o impacto que cada estilo tem sobre o leitor. Pela importância do procedimento e por entendermos que essa é a resposta-chave para explicar o sucesso de público da literatura alencariana, reproduzimos um dos exemplos ${ }^{11}$ :

\section{Fr. Luís de Sousa}

E ra uma árvore de tão desmesurada grandeza, que dentro do tronco, que de muita antiguidade tinha aberto e oco se armou uma mesa, e o arcebispo se assentou a ela em uma cadeira, e por memória no mesmo sítio e assento visitou a freguesia, e tinha também lugar dentro a testemunha que vinha dizer seu dito. (Iracema, 82-83) (Grifos de Alencar)

\section{J osé de Alencar}

E ra uma árvore de tão desmesurada grandeza, que dentro no tronco da muita antiguidade aberto e oco, armou-se uma mesa: a ela assentou-se o arcebispo em uma cadeira, onde por memória visitou a freguesia, havendo aí lugar também para a testemunha que vinha dizer seu dito. (id.)

A explicação de Alencar para o processo de estilização do período a que submeteu o período é pobre. Para ele contou apenas a eliminação das conjunções, e os cortes de sequência; as inversões na ordem dos elementos e a alteração da colocação pronominal, a eliminação e inserção da pontuação, nada disso foi explicado. Foi o conjunto de procedimentos, todavia, que deu o "tom brasileiro" e não apenas a eliminação das conjunções, não obstante algumas trocas que a priori são mais de caráter lusitanizante, como a colocação enclítica do pronome (antes proclítica) e a escolha do verbo haver (havendo aí lugar) em substituição a ter (tinha lugar).

11 Apud Pinto (1978). 
Para concluir, lembramos que, em geral, o caráter dos argumentos de J osé de Alencar é, de um lado, arbitrário e, de outro, conservador, quando se trata de defender, do ponto de vista ortográfico e gramatical, sua linguagem, pois o que se vê, em resumo, é:

1. preferência por uma regra sua, em detrimento da convenção (tanto no campo ortográfico quanto gramatical);

2. recorrência ao latim e a línguas românicas, para justificar-se perante críticas;

3. recorrência ao português antigo e clássico, para justificar-se perante críticas.

Não se veem, na produção metalinguística do escritor, argumentos baseados no uso real da língua.

\section{Conceito DE USO}

As referências de Alencar ao uso ocorrem na maioria das vezes quando trata da relação do escritor com a língua. Como já comentamos, para ele, o papel do escritor é "organizar a língua” a partir do uso de que dela faz o povo, talvez pudéssemos falar em estilizar a língua a partir do uso. Por isso, em seu texto essa ideia de que o uso é a base da linguagem literária fica subliminar, mas o autor não esclarece como seria esse aproveitamento. Aliás, referências feitas ao uso, em geral, são sempre depreciativas.

Em um trecho do texto Bênção paterna, no qual trata, ainda, de falar da tarefa do escritor diante da língua, por exemplo, aparece uma referência nada abonadora ao uso que o povo faz da língua. Leiamos o trecho que fala por si só:

Sobretudo compreendam os críticos a missão dos poetas, escritores e artistas, nesse período especial e ambíguo da formação de uma nacionalidade. São estes operários incumbidos de polir o talhe e as feições da individualidade 
que se vai esboçando no viver do povo. Palavra que inventa a multidão, inovação que adota o uso, caprichos que surgem no espírito do idiota inspirado tudo isto lança o poeta no seu cadinho, para escoimá-lo das fezes que porventura lhe ficaram do chão onde esteve, e apurar o ouro fino. (Bênção, p. 94) (Grifamos)

A que uso se refere o autor? Somente o da língua falada? Ou "a palavra do idiota inspirado" remete a algum uso escrito também? Sobre essa questão não é possível fazer afirmação definitiva, mas a impressão que dá tal declaração, e outras de mesmo diapasão, é que o sentido de uso, nesse caso, seja: a prática linguística popular, não importa em que modalidade.

Na Questão filológica, ${ }^{12}$ o autor, para responder às críticas gramaticais que Antônio Henriques Leal formulou, recorreu a outro conceito de uso, como se vê em:

O uso tem admitido porém um artigo em alguns casos, especialmente quando o nome é plural feminino regido pela preposição a. Como às pressas, às carreiras, às rebatinhas; ainda que também se diz a bragas enxutas, a trechos e aos trancos; ao certo, na verdade etc. (Questões, 106) (Grifos do autor)

Aqui o sentido do termo parece claro: uso culto escrito, já que na fala a presença ou ausência do acento grave não é sentida. Também a expressão "uso geral" é empregada nesse mesmo sentido, quando, em resposta ao mesmo contendor, disse: “(...) concluiu o autor das Locubrações (sic), que eu não estou firme nas regras por mim estabelecidas, ao avesso do uso geral; tanto que não as sigo na prática, e as transgrido frequentemente." (id., 115).

Em outro trecho, parece que a palavra é empregada no sentido do falar corrente. Nesse caso o autor trata da regência

12 Apud Pinto (1978). 
de alguns verbos, uns de movimento e outros de estado, como moro na rua de..., estou na janela e cheguei em casa, regidos preferencialmente com a preposição em no português do Brasil, diferentemente do uso europeu, que a realiza com a preposição a. E aí diz:

Como, porém, os dous melhores mestres que eu conheço da arte de falar são o bom senso e ousa e eu todos os dias tomo lição com eles, considero-me habilitado para afirmar que nesta questão damos quinau nos nossos irmãos mais velhos. (Cancioneiro, 124)

Alencar diz isso para defender sua preferência pela maneira de dizer brasileira. Para defender sua posição, primeiro confessa não ser filólogo nem gramático, mas como "todo homem tem por força uma duela de doudo e outra de médico”, ele arrisca-se na tarefa de condenar o uso português. Os argumentos de que lança mão são do emprego da preposição no latim: "Releva contudo observar que os bons autores [latinos] preferiam geralmente empregar com verbos de repouso e permanência a preposição in, de preferência a ad.”. A preferência pelo uso brasileiro tem, então, uma justificativa erudita, não popular. A conclusão de tudo, porém, é a preferência pela regra que formula para uso pessoal:

Eu direi, pois, estar à janela, de uma pessoa que avizinhou-se dela, ou a ocupou de passagem ligeiramente: a estar na janela, da que se acha positivamente nela e aí se demora. Da mesma forma, chegar à casa é tocar-lhe a soleira: e chegar em casa, achar-se dentro. (Cancioneiro, $125)^{13}$ (Grifos do autor)

Em síntese, também nessa questão é impossível não dizer da contradição de Alencar. O que se pode concluir é que o

13 Apud Pinto (1978). 
autor trabalhou com várias acepções para a palavra uso, sem oferecer ao leitor nenhum esclarecimento sobre cada uma delas Dentre as acepções mais recorrentes anotamos: uso vulgar, deve ser rejeitado; uso geral, deve ser corrigido; uso literário, deve ser imitado; uso pessoal, oferecido à imitação .

\section{ÚLTIMAS CONSIDERAÇÕES}

É lugar comum dizer que Alencar "preparou o caminho" por onde passou o Modernismo, ou que ele foi o Mário de Andrade do século XIX. No sentido de "brigar" pela autonomia da língua portuguesa do Brasil, sim, ele foi um precursor. Foi um bandeirante. Mas entre Alencar e Mário há diferenças imensas. Fiquemos apenas com duas: Mário foi mais pesquisador, Alencar foi mais intuitivo. Mário conseguiu levar o escritor brasileiro a, aos poucos, libertar-se do passadismo. Alencar, não, bradou por uma língua "menos passadista”, mas foi contraditório e, ele próprio, praticava o passadismo, como suas justificativas, para os "erros" dos quais foi condenado, revelam ${ }^{14}$. Alencar fez um trabalho meio quixotesco, sozinho, sem nem ao menos um Sancho Pança.

Além do mais, depois de Alencar veio Machado de Assis.

Machado e Alencar eram amigos, distantes, é certo, porque Alencar não era de amizades. Lira Neto (2006, p. 137) conta como os dois se conheceram, diz que José de Alencar publicou, como diretor do Diário do Rio de Janeiro, no dia 7

14 Bechara (2001) não concorda com as posições aqui defendidas, mas seu artigo mostra quanto Alencar permaneceu ligado ao português clássico. Com os mesmos textos aqui analisados, mas não tomados sistemicamente, Bechara desenvolve raciocínio diverso deste aqui apresentado. Também Melo (1972), ocupa-se em mostrar o quanto Alencar foi "correto" em sua linguagem literária (com o que não nos ocupamos aqui), mas afirma que "é preciso distinguir entre a posição teórica de Alencar e a posição prática, isto é, examinar as suas ideias a propósito da questão e observar como êle escreveu, como êle usou a língua culta.". Em se tratando de Alencar, vale a polêmica. 
de fevereiro de 1856, o primeiro poema de Machado. O próprio Machado conta esse encontro no texto A estátua de José de Alencar, em que diz: "A sensação que recebi no primeiro encontro pessoal com ele foi extraordinária; creio agora que não lhe disse nada, contentando-me de fitá-lo com olhos assombrados do menino Heine ao ver passar Napoleão.".

Machado acompanhava a carreira de Alencar e o apoiava, comparecendo às apresentações de suas peças e trocando ideias, de vez em quando, com ele. Também, fazendo-lhe críticas, amenas, como registra Lira Neto. No famoso texto Notícia da atual literatura brasileira - Instinto de nacionalidade, de 24 de março de 1873, Machado elogia Alencar, quando, tratando do teatro, diz: "Apareceram então os dramas e comédias do Sr. J osé de Alencar, que ocupou o primeiro lugar na nossa escola realista e cujas obras Demônio familiar e Mãe são de notável merecimento.”. O teatro de Alencar é também assunto da crítica de Machado em 1866, no Diário do Rio de Janeiro. No mesmo jornal, em 23 de fevereiro de 1866, Machado elogiou Iracema, ${ }^{15}$ dizendo que o livro era "um poema em prosa", embora tivesse dito que o poema havia perdido força na forma de romance. $\mathrm{E}$, temeroso dos melindres do autor, que ele conhecia, finalizou a crítica pedindo que Alencar não parasse de escrever, como prometera, se o público não reagisse bem, ou não reagisse, ao romance recém-publicado. Mas Iracema foi um sucesso de público e de crítica, à exceção daquelas que lhe condenaram a linguagem, como mostramos. $\mathrm{E}$ as críticas de Machado eram econômicas.

No Instinto de Nacionalidade vemos que Machado de Assis dialoga com tudo o que se falava na época sobre a língua. A língua, inclusive, é o item final do texto. Em uma página, o autor passa em revista toda a discussão linguística que tinha curso na época, respondendo às dúvidas que iam ficando no ar. Sua posição fica clara na primeira frase: "En-

15 Texto também publicado em Machado de Assis - Obra Completa, vol. III, p. 848. 
tre os muitos méritos dos nossos livros nem sempre figura o da pureza da linguagem". Depois, põe-se atualizado com o fato da "variação" temporal e social da linguagem ${ }^{16}$ e nega o apego ao passadismo, embora declare ser favorável à leitura dos clássicos e ao aproveitamento do que têm a oferecer ao escritor. ${ }^{17}$ Quanto ao aproveitamento da linguagem corrente é bastante restritivo, mas deixou clara a sua opinião de que o escritor não deve incorporar todas as nuanças do uso corrente da língua. ${ }^{18}$

Dentre tantas afirmações de Machado sobre assuntos que interagem claramente com a discussão que se desenrolava com Alencar e seus contendores, uma, em especial, denuncia esse dialogismo: o fato de ser Alencar um "fabricante de livros"19. Machado dá o seguinte conselho aos jovens:

Outra coisa que eu quisera persuadir a mocidade é que a precipitação não lhe afiança muita vida aos seus escritos. Há um prurido de escrever muito e depressa; tira-se disso glória, e não posso negar que é caminho de aplausos. (...) Faça muito embora um homem a volta ao mundo em oitenta dias; para uma obra-prima do espírito são precisos alguns mais.

As características da literatura brasileira arroladas por Machado, para concluir sua análise sobre a literatura brasileira até aquela época, revelam, de um lado, suas posições

16 "Não há dúvida que as línguas se aumentam e alteram com o tempo e as necessidades dos usos e costumes".

17 "Querer que a nossa língua pare no século de quinhentos, é um erro igual ao de afirmar que sua transplantação para a América não lhe inseriu riquezas novas."

18 "A influência popular tem um limite; e o escritor não está obrigado a receber e dar curso a tudo que o abuso, o capricho e a moda inventam e fazem correr. Pelo contrário, ele exerce também uma grande parte de influência a este respeito, depurando a linguagem do povo e aperfeiçoando-lhe a razão".

19 Não tratamos de críticas dessa natureza neste trabalho porque não há conexão direta com o problema da língua. 
diante da literatura e da língua, e, de outro, denunciam sua opinião, também sobre Alencar, não somente pelos adjetivos positivos como pelos negativos que lhe atribui. No cenário da época, a estrela era Alencar, além disso, seus defeitos mais comuns ficaram conhecidos do público pelas polêmicas divulgadas nos jornais. Ouçamos a voz de Machado e vejamos resumidas as críticas aqui comentadas:

Viva imaginação, delicadeza e força de sentimentos, graça de estilo, dotes de observação e análise, ausência às vezes de gosto, carência às vezes de reflexão e pausa, língua nem sempre pura, nem sempre copiosa, muita cor local, eis aqui por alto os defeitos de as excelências da atual literatura brasileira, que há dado bastante e tem certíssimo futuro.

As opiniões de Machado de Assis nesse trecho de avaliação da literatura da época não deixam dúvidas de que o projeto literário de Alencar não teria sequência.

\section{BiBLIOGRAFIA}

ASSIS, Machado. Machado de Assis - obra completa (vol. III). Rio de Janeiro : Nova Aguilar, 1986.

BAKHTIN, Mikail. Estética da criação verbal. Tradução do francês por Maria Ermantina Galvão Gomes Pereira. São Paulo: Martins Fontes, 1992. [1979, Moscou]

BECHARA, Evanildo. José de Alencar e a língua do Brasil. Revista Brasileira, Jul./Ago./Set., Ano VII, 2001.

LEITE, Marli Quadros. Metalinguagem e discurso - a configuração do purismo brasileiro. São Paulo : Humanitas, 1999.

LEROY, Maurice. As grandes correntes da linguística moderna. 2. ed. Trad. Izidoro Blikstein et al. São Paulo : Cultrix, 1982.

LIRA NETO. O inimigo do rei. Uma biografia de José de Alencar, ou uma mirabolante aventura de um romancista que colecionava desafetos, azucrinava D. Pedro II e acabou inventando o Brasil. São Paulo: Globo, 2006. 
MELO, Gladstone Chaves de. Alencar e a "língua brasileira". 3. ed. Conselho Federal de Cultura, 1972.

PINTO, Edith Pimentel. O português do Brasil: textos críticos e teóricos. 1- 1820/ 1920 - fontes para a teoria e a história. Rio de J aneiro/São Paulo: Livros Técnicos e Científicos/EDUSP, 1978.

O português do Brasil: textos críticos e teóricos. 1- 1920/1945 fontes para a teoria e a história. Rio de Janeiro/São Paulo : Livros Técnicos e Científicos/EDUSP, 1981.

A contribuição de Alencar para uma expressão brasileira. In: J osé de Alencar: sua contribuição para a expressão brasileira. Edições Cadernos da Serra, Col. Imbuí, Ensaios e Crônicas, n. 4. s/d e $\mathrm{s} / 1$.

RIBEIRO, J oão. A lingua nacional - notas aproveitaveis. São Paulo : Monteiro Lobato \& Cia, 1921.

SILVA NETO, Serafim da. A língua portuguesa no Brasil - problemas. Rio de J aneiro : Acadêmica, 1960.

. História da língua portuguesa. 4. ed. Rio de Janeiro: Presença, 1986b. [1 ${ }^{\text {a }}$ ed. 1957]

Introdução a o estudo da língua portuguesa no Brasil. 5. ed. Rio de J aneiro : Presença, 1986a. [1 ${ }^{\text {a }}$ ed. 1950]

\section{FonTES}

ALENCAR, J osé (1865). Poscrito. Diva, perfil de mulher. 4. ed. Rio de Janeiro: Garnier, 1891, p. 193-215. In: O português do Brasil: textos críticos e teóricos. 1- 1920/1945 - fontes para a teoria e a história. Rio de Janeiro/São Paulo: Livros Técnicos e Científicos/ EDUSP, 1978, p. 55-67.

ALENCAR, J osé (1870). Pós- escrito (à $2^{\mathrm{a}}$ ed. de Iracema). Iracema. Rio de Janeiro : J osé Olípio, 1965, p. 161-181. In: O português do Brasil: textos críticos e teóricos. 1- 1920/1945 - fontes para a teoria e a história. Rio de Janeiro/São Paulo : Livros Técnicos e Científicos/EDUSP, 1978, p. 67-86.

ALENCAR, José (1872). Bênção paterna.Sonhos d'Ouro. 2. ed. São Paulo : Melhoramentos, s. d. In: . O português do Brasil: textos críticos e teóricos. 1- 1920/1945 - fontes para a teoria e a história. Rio de J aneiro/São Paulo: Livros Técnicos e Científicos/EDUSP, 1978, p. 86- 96. 
ALENCAR, J osé (1873). Questão filológica. Iracema. Rio de Janeiro : José Olípio, 1965, p. 218-240. In: $O$ português do Brasil: textos críticos e teóricos. 1- 1920/1945 - fontes para a teoria e a história. Rio de Janeiro/São Paulo : Livros Técnicos e Científicos/ EDUSP, 1978, p.96-121.

ALENCAR, J osé (1874). Nosso cancioneiro. O nosso cancioneiro. Cartas ao Sr, Joaquim Serra. Introdução e notas de Manuel Esteves e M. Cavalcanti Proença. Rio de janeiro : Livr. S. José, 1962, p. 22 24; 27-30; 53-60; 61-70. In: $O$ português do B rasil: textos críticos e teóricos. 1- 1920/ 1945 - fontes para a teoria e a história. Rio de Janeiro/São Paulo : Livros Técnicos e Científicos/EDUSP, 1978, p. $122-142$.

BARROS, Domingos Borges (Visconde de Pedra Branca) (1824-1825). Brasileirismos. Introduction à l'Atlas ethnographique du globe, p. 172-75. In: $O$ português do Brasil: textos críticos e teóricos. 1 - 1920/ 1945 - fontes para a teoria e a história. Rio de Janeiro/São Paulo: Livros Técnicos e Científicos/EDUSP, 1978, p. 5-7.

DIAS, Gonçalves (1857). Carta ao Dr. Pedro Nunes Leal.Estante clássica da revista da língua portuguesa. Dir. de Laudelino Freire. Rio de janeiro : dez. de 1921, vol. VII, p. 127-132. In: O português do B rasil: textos críticos e teóricos. 1- 1920/1945 - fontes para a teoria e a história. Rio de Janeiro/São Paulo : Livros Técnicos e Científicos/EDUSP, p. 33-38.

SOARES, Macedo (1860). Diccionario brazileiro da língua portugueza. Elucidario etymologico - critica Palavras e phrases que, originarias do Brazil, ou aqui populares, se não encontram nos diccionarios da lingua portuguesa, ou neles vêm com forma ou signifficação differente (1875-1888). S.l.

VARNHAGEN (1847). Prólogo. Florilégio da poesia brasileira. Lisboa : Impr. Nacional, 1850, p. V a X e XIX a XX. In: $O$ português do B rasil: textos críticos e teóricos. 1- 1920/1945 - fontes para a teoria e a história. Rio de Janeiro/São Paulo : Livros Técnicos e Científicos/EDUSP, 1978, p. 19-22.

ABSTRACT: This article aims to study, within the linguistic historiography, the metalanguage of José de Alencar produced in the period of 1865 and 1870. Despite the fact that Alencar's speech is still the founding speech of criticism of the Brazilian Portuguese variety, the text reveals that his linguistic thought was unclear and his objective, 
beyond fighting for the "Brazilian language" autonomy and independency in opposition to the European variety, was to justify and defend his own literary language.

Keywords: Brazilian Portuguese, linguistic historiography, linguistic variety, metalanguage. 